\title{
Genetical studies of nectar and pollen production in sunflower
}

\author{
F Vear ${ }^{1^{*}}$, M Pham-Delegue ${ }^{2}$, D Tourvieille de Labrouhe ${ }^{1}$, R Marilleau 2 , \\ Y Loublier ${ }^{2}$, M le Métayer ${ }^{2}$, P Douault ${ }^{2}$, JP Philippon ${ }^{1}$ \\ 1 INRA, Station d'Amélioration des Plantes, Domaine de Crouelle, 63039 Clermont-Ferrand Cedex; \\ 2 Laboratoire de Neurologie Comparée des Invertébrés, INRA-CNRS (UA 1190), 91440 Bures-sur-Yvette, France
}

(Received 24 January 1989 ; accepled 24 January 1990)

\begin{abstract}
Summary - The composition and quantitative characteristics of nectar and pollen production were studied in 2 series of parental lines and the hybrids obtained from a factorial cross. Nectar analysis by gas chromatography and enzyme electrode technology were compared; the former was found to be the most satisfactory. Nectar sugar composition was very stable, with $\mathbf{5 2 \%}$ fructose and $\mathbf{4 8 \%}$ glucose. Sucrose was rarely present in trace amounts. Significant differences were found in the volume of nectar per floret, percentage dry matter and energy value per floret. Heritable effects appeared most clearly for nectar volume per floret. The number of pollen grains per floret varied between plants but there were significant genotypic and parental effects. Possible relations between nectar and pollen production and agronomic characteristics are discussed.
\end{abstract}

sunflower / nectar / pollen / analysis / heredity

Résumé - Études de la variabilité génétique de la production de nectar et de pollen chez le tournesol. La composition et les caractéristiques quantitatives des productions de nectar et de pollen ont été étudiées sur 2 séries de lignées de tournesol et les hybrides issus de leurs plans factoriels de croisement (6x6 et $3 \times 3$ ). Des analyses du nectar par chromatographie en phase gazeuse et par une méthode électrolytique ont été comparées. Si la corrélation entre les valeurs moyennes par génotype mesurées par les 2 méthodes est significative, celle entre les valeurs par plante ne l'est pas, surtout parce que la méthode électrolytique fait apparaitre des concentrations de saccharose qui sont inexactes selon les analyses en chromatographie (tableau I). Ainsi seule la chromatographie peut être utilisée. La composition des sucres du nectar est très stable, avec aucune différence significative entre 12 lignées et leurs 36 hybrides (tableau II). II y a environ $52 \%$ de fructose et $48 \%$ de glucose. Le saccharose est rarement présent et en faible quantité. II existe des différences significatives entre génotypes en ce qui concerne le volume de nectar par fleuron (tableau III), le pourcentage de matière sèche (tableau IV) et la valeur énergétique par fleuron (tableau V). Le volume de nectar par fleuron est la variable pour laquelle les effets héritables paraissent les plus nets; une lignée, GH, produisant 0,26 $\mu$ l par fleuron, donne des hybrides avec en moyenne jusqu'à 0,31 $\mu$ l par fleuron. Alors que les autres génotypes produisent en moyenne $0,10 \mu \mathrm{l} /$ fleuron. Le nombre de grains de pollen par fleuron varie entre plantes d'un même génotype. Néanmoins il y a des effets génotypiques (tableau VI) et parentaux (tableau VII) pour ce caractère. Le nombre de grains par fleuron moyen varie de 25218 à 42087 selon le génotype. Aucune relation avec la résistance ou sensibilité au Sclerotinia n'apparaît en ce qui concerne les productions de nectar et de pollen (tableau VIII). II y a une tendance pour que les génotypes produisant moins de pollen soient un peu plus riches en huile, mais la corrélation n'est pas significative.

tournesol / nectar / pollen / analyse / hérédité

\section{INTRODUCTION}

Pollen and nectar provide nourishment for organisms ranging from micro-organisms to man. However, the primary importance of pollen is as a carrier of the male gametophyte, so that all use of pollen as food is secondary and represents pollen theft. In contrast, nectar clearly has no other function in angiosperm flowers than to provide food in plant-pollinator relationships.

It is likely that natural selection has tended to produce a food reward for cross-pollination. The relationship between sunflowers and their pollinating insects is a model of great interest.

* Correspondence and reprints 
Sunflowers are preferentially cross-pollinated by insects, mainly honey bees (Macgregor, 1976; Radford et al, 1979) and other apoids such as bumble bees (Freund, Furgala, 1982). Both plant and insect benefit from this relationship: sunflower varieties are $F_{1}$ or 3-way hybrids produced using cytoplasmic male sterility; hybrid seed production depends on the transport of pollen by bees from the male parent to the male sterile female parent (Parker, 1981a). The hybrids themselves are bred for self-fertility but even for the most self fertile genotypes, it has been demonstrated that cross pollination by insects induces a notable increase in seed yield and oil content (Furgala et al, 1979) as well as more rapid seed set and thus improved earliness (Madeuf, unpublished data).

In parallel, sunflower floral structure is particularly adapted to attract honey bees. They have a strong aroma (Etievant et al, 1984), large ligulate florets (Harbourne, Smith, 1978), abundant nectar secretion with large quantities of sugar (Tepedino, Parker, 1982). There have been many studies of nectar secretion and sugar content. By far the largest dry weight of nectar is sugar, but various workers have demonstrated the presence of proteins, lipids, alkaloids and other compounds (Baker,Baker, 1976) which are probably of great importance in nutrition but represent less than $0.03 \%$ of dry weight.

For the majority of nectars, the sugar content is constituted by glucose, fructose and sucrose. It is known that their relative proportion in nectar is characteristic according to family but tends to remain constant for a given species (Wykes, 1952). In sunflower it had been reported that differential distribution of honey bees between the parental lines of 2 hybrids was related to differences in nectar composition, and more precisely to the relative amounts of sucrose (Pham Delegue et al, 1985; Fonta et al, 1985). However, it remained to determine whether these differences existed in a wide range of genotypes and whether they were heritable.

Pollen grains contain a wide range of amino acids, both in the free state and as protein, as well as lipids, carbohydrates and vitamins (Stanley, Linskens, 1974). The reward to a flower visitor is usually pollen produced in excess of the amount directly needed in pollination. However, it is not clear whether pollen production is characteristic of a given genotype.

In addition, pollen and nectar could be of importance in the determination of certain agronomic characteristics. Firstly, 2 of the most important diseases attacking sunflowers, Sclerotinia sclerotiorum and Botrytis cinerea can result from infections occurring on the floral surface during flowering, and especially during the period of pollen and nectar production (SaysLesage, Tourvieille de Labrouhe, 1988). The nectar and pollen, rich in nutritive substances could favorise spore germination and mycelial growth, and thus disease development. Secondly, Vear (1984) showed that male sterile plants have slightly higher oil contents and yields than comparable male fertile plants and suggested that this could be related to the saving in energy normally used for pollen production. Renard et al (1987) observed the same effect in rape-seed. Limitation in resources is an important aspect of pollen production and utilisation biology, although generally natural populations producing pollen are studied (Stanton, Preston, 1988), which is rather different from comparison of male sterile and male fertile plants.

This paper describes studies of the heredity of pollen and nectar production using different analytical methods, and the relations between these characters and Sclerotinia susceptibility and oil content.

\section{MATERIALS AND METHODS}

\section{Sunflower genotypes}

Two series of parents and $F_{1}$ hybrids from factorial crosses were studied. The parental lines were chosen to represent a wide range of origins and to cover the known range of Sclerotinia resistance and susceptibility (Vear and Tourvieille de Labrouhe, 1988). In most cases, pollen and nectar production had not been studied before. The lines below are given in order of increasing susceptibility to Sclerotinia.

(a) 1985: $6 \times 6$ Female parents : SD, B11A3, F10, $62, \mathrm{GU}, \mathrm{GH}$

Males parents : PAC1, HA61, PRS5, RHA274, V135, RHA266

(b) 1986: 3 × 3 Female parents : B11A3, F10, GH Male parents : HA61, RHA266, V135

The female parents B11A3 and F10 have genic male sterility, the others cytoplasmic male sterility, but of course, for the studies of inbred lines, the male fertile forms were used. Of the male parents, only HA61 and V135 were not restorers.

\section{Nectar analysis}

\section{Sampling}

The samples collected in 1985 were obtained on a single pooled sample from several plants, using the number of florets of the internal ring required to provide $10 \mathrm{ml}$ of nectar. In 1986, 3 repetitions (plants) of each genotype (except the late flowering $F 10, F 10 x$ Rha 266, F10 x V135) were collected individually to provide both quantitative and qualitative data. 
The samples were obtained using graduated glass micropipettes (internal diameter $1 \mathrm{~mm}$, volume $5 \mathrm{ml}$ ) in florets at anthesis on capitula during the first half of flowering. The capitula were covered with paper bags $24 \mathrm{~h}$ before sampling, in order to obtain homogeneous evaporation conditions and to avoid visits by insects. The samples were conserved at $-25^{\circ} \mathrm{C}$ until chemical analysis.

\section{Gas chromatographic analysis}

This technique is sufficiently precise and sensitive to analyse small quantities of nectar, in the region of $2 \mathrm{ml}$. The method was developed by Marilleau et al (in preparation) from a technique of Brohst and Lott (1966), used by Bosi (1973) for analysis of partially dehydrated nectars which permits determination only of the relative percentage of sugars in the dry matter. It was completed, following Black and Bagley (1978) by the introduction of an internal standard permitting calculation of the real quantities of sugars present.

\section{Sample preparation}

The samples were dehydrated during 1 night, under partial vacuum, in the presence of $\mathrm{P}_{2} \mathrm{O}_{5}$, then dissolved in a control solution of $2 \mu \mathrm{g}$ of triphenyl ethylene $/ \mu l$ pyridine. The dilution volume varied according to the quantity of nectar obtained. When only 1 to $1.5 \mathrm{ml}$ was available, the dilution volume was $0.5 \mathrm{ml}$, otherwise it was $1 \mathrm{ml}$.

0.45 or $0.50 \mathrm{ml}$ of hexamethyl disilazine were added, giving a complete replacement of the free $\mathrm{OH}$ groups of sugars by trimethylsilyl groups (Buzon et al, 1968) to permit satisfactory separation of the sugars along the column. This was followed by addition of 0.05 to $1 \mathrm{ml}$ of trifluoracetic acid which fixes water molecules still present. The final dilution volume was $2 \mathrm{ml}$ for large quantities of nectar and $1 \mathrm{ml}$ for smaller quantities.

Triphenyl ethylene was chosen as an internal standard due to its migration duration, which does not interfere with the sugars studied; in addition, not being a sugar, it undergoes no structural changes.

\section{Preparation of the reference mixture}

A solution was prepared with $1 \mathrm{ml}$ of the triphenyl solution described above, in which $2 \mathrm{mg}$ of each reference sugar (sucrose, fructose and glucose) were dissolved. Then, as for the nectar samples, the sugars were transformed. All components then had a concentration of $1 \mu \mathrm{g} / \mathrm{ml}$. The reference mixture was injected after every 4 or 5 samples and at least once a day.

\section{Chromatograph characteristics}

- Girdel 3000 chromatograph with automatic temperature control.

- Column of pyrex glass (length $3 \mathrm{~m}$, internal diameter

$2 \mathrm{~mm})$.

- Stationary phase OV 17 at $3 \%$ on chromosorb WHP.

- Column temperature from $185^{\circ} \mathrm{C}$ to $280^{\circ} \mathrm{C}$ with an increase of $2 \% \mathrm{~min}$.

- Detector temperature $300^{\circ} \mathrm{C}$.

- Nitrogen (gas vector) pressure $2 \mathrm{~kg} / \mathrm{cm}^{2}$ flow : 20 $\mathrm{ml} / \mathrm{min}$.
- Integrator/recorder Delsi enica 10.

- Volume injected $2 \mu \mathrm{l}$.

\section{Parameters}

The internal standard method of Black and Bagley (1978) was used: the migration coefficients (Ki) of each sugar were calculated from the reference mixture.

$\mathrm{K}=A^{\prime}$ 's where: A's : area of the standard peak

$A^{\prime} i \quad A^{\prime} i$ : area of a given sugar peak

The concentration of each sugar is obtained by dividing the area under the peaks of the constituents of an unknown sample, multiplied by its migration coefficient, by the area of the peak obtained with a known quantity of the internal standard. The calculation is the following :

$\mathrm{C}_{\mathrm{i}}=\frac{a_{c}}{a_{s}} \times{ }^{k_{\mathrm{i}}} \times \frac{w_{s}}{w_{c}} \times 100$

Where $a_{c}=$ area of compound $i$ in sample

$a_{s}=$ area of internal standard in sample

$w_{s}=$ weight of internal standard in sample

$w_{c}=$ weight of sample

This method takes into account changes in the efficiency of the column and avoids losses of time required for standard graph calculations.

Bolten et al (1979) suggest the adoption of a standard expression for sugar contents in nectar. Thus, sugar concentrations obtained from gas chromatography, expressed as $\mathrm{mg}$ sugar/100 $\mathrm{mg}$ nectar were converted using tables in the Handbook of Chemistry and Physics (1988) into $\mathrm{mg}$ sugar/100 ml nectar.

\section{Enzyme electrode technology}

This technique was carried out on the samples collected in 1986. Successive measurements of each sugar of the nectar were provided by the YSI Model 27 Industrial Analyser (Bioblock). Samples were diluted in $100 \mathrm{ml}$ of distilled water; $25 \mu \mathrm{l}$ of the solution were injected into a sample chamber containing a $5 \mu \mathrm{m}$ thickness of Nucleopore polycarbonate membrane material which has pores of nominally $0.03 \mu \mathrm{m}$ diameter. The rate of the following chemical reactions is limited primarily by the rate of this first diffusion step. Since diffusion is a physical process, much simpler and more predictable than enzyme kinetics, this results in improved linearity, calibration stability and freedom from enzyme inhibition errors. Once past the Nucleopore barrier, the sugar encounters a thin $(1 \mu \mathrm{m})$ layer of immobilised enzymes of very high activity per unit volume.

\section{Glucose and fructose measurements}

On the membrane, the following reactions occur almost instantaneously:

For glucose:

$$
\mathrm{O}_{2}+\text { glucose } \underset{\text { oxidase }}{\stackrel{\text { glucose }}{\longrightarrow}} \mathrm{H}_{2} \mathrm{O}_{2}+\mathrm{D} \text { glucano - lactone }
$$

For fructose :

$$
\mathrm{O}_{2}+\text { fructose } \underset{\text { oxidase }}{\stackrel{\text { galactose }}{\longrightarrow}} \mathrm{H}_{2} \mathrm{O}_{2}+\text { lactone }
$$


The hydrogen peroxide produced diffusing towards a probe anode is oxidised electrochemically. This gives rise to the probe signal current. The current flow at the anode is directly proportional to the hydrogen peroxide concentration and hence to the sugar concentration.

The readings, which represented the sugar free assay of the diluted sample in units of $\mathrm{mg} / 100 \mathrm{ml}$, were recorded. The weight of sugar (expressed as $\mathrm{mg} / 100$ $\mathrm{ml}$ of nectar) was then obtained by multiplication of the reading with the dilution rate.

\section{Sucrose measurement}

For the determination of sucrose in the presence of glucose, the glucose concentration of the sample is determined both before and after the complete hydrolysis (invertion) of the sucrose present to glucose. The sucrose is converted externally according to an invertion:

sucrose $\underset{\text { mutarotase }}{\stackrel{\text { invertase }}{\longrightarrow}} \alpha-D$ glucose and a mutarotation :

$\alpha-D$ glucose $\longrightarrow \beta-D$ glucose. The sucrose concentration is calculated from the difference between the 2 glucose concentrations.

\section{Pollen counts}

Pollen was collected from male fertile hybrids and the male fertile forms of the parental lines.

In 1985 , the pollen counts were made on the $6 \times 6$ factorial, except for 4 hybrids and 2 inbred lines, with 4 counts per plant and 5 plants per genotype. Observations were completed in 1986 using 3 controls, observed both years (SD $\times$ PAC1, GH $\times$ RHA266, F10 $\times$ V135), to permit correction to the 1985 levels (multiplication of 1986 data by 1.067 ).

Following acetolysis and ultrasonic treatment, pollen grains were counted using a particles counter (Coulter Counter ZB Coultronics) according to the method described by Loublier et al (1986).

Ten mature, non-dehiscent florets were randomly collected from sunflower heads at mid-flowering. Samples of 10 florets were put in a laboratory vessel and ground in a few drops of distilled water in a glass homogeniser. Ten $\mathrm{ml}$ pure sulphuric acid were then added to act on the substrate for $24 \mathrm{~h} ; 90 \mathrm{ml}$ of a $2 \%$ aqueous solution of triton were added and centrifuged until a single sediment was obtained. Each centrifugation was for $7 \mathrm{~min}$ at $3000 \mathrm{rpm}$ (about $700 \mathrm{~g}$ ). Acetolysis was conducted following the method of Erdtman (1960). The sediment was dissolved in 5 $\mathrm{ml}$ ethanol at $95 \%$ and subjected for $15 \mathrm{~min}$ to an ultrasonic treatment with a frequency of $50 \mathrm{k} / \mathrm{cycles} / \mathrm{s}$. The particles were reconcentrated by centrifugation and rediluted in $50 \mathrm{ml}$ Isoton. This solution was used to make 4 replicate measurements with the "Coulter Counter".

\section{Sclerotinia reaction}

Reaction to Sclerotinia was assessed by 2 methods in 1986. Firstly by counts of the percentage of plants attacked under natural conditions (with irrigation at flowering). This method was described in detail by Vear and Tourvieille de Labrouhe (1987). In a randomised block design with 46 plants per plot and 4 replicates, the plants were maintained with liquid water on the capitulum surface for at least $48 \mathrm{~h}$ during flowering to favorise Sclerotinia infection. Environmental effects on symptom development were eliminated by comparison of results with those of plots of a control hybrid flowering at different dates. The results are thus expressed as an index (Sclerotinia Index 1) calculated by :

Number of plants attacked of a given genotype

Number of control plants attacked with same flowering date

Secondly, artificial infections were made with suspensions of ascospores during flowering (Tourvieille de Labrouhe and Vear, 1984). In this case, percentage infection is very high and resistance is measured by the delay in symptom appearance. As with semi-natural attack, environmental influences are eliminated by comparison with a control. The results are latency indexes (Sclerotinia index 2 in table II) calculated as :

Number of days from infection to symptom appearance of a given genotype

Number of days from infection to symptom appearance in controls with same flowering date.

Thus, for natural attack, higher figures indicate susceptible genotypes, whereas on the contrary, for the ascospore infection, the most resistant genotypes have the highest indexes (Vear and Tourvieille de Labrouhe, 1988).

\section{Oil contents}

These are measured by NMR (Brucker Minispec 10) on $3 \mathrm{~g}$. samples of seed at $4-6 \%$ moisture content.

\section{Studies of heredity}

Genotypic differences were studied by analysis of variance : parental effects and interactions by factorial analysis and the relation between the phenotypes of inbred lines and those of their hybrids by correlations between results for inbred lines and the means of those obtained for their hybrids.

\section{RESULTS}

\section{Nectar}

\section{Effect of analytical methods}

The data (table I) obtained from gas chromatography and enzyme electrode technology for the nectar samples collected on the parents and $F_{1}$ hybrids of the $3 \times 3$ factorial cross of 1986 were compared. Samples from the female parent 
Table I. Nectar production in 1986, measured by gas chromatography (C) and by the enzyme electrode technique (E), and oil contents for the inbred lines and hybrids of a $3 \times 3$ factorial cross.

\begin{tabular}{|c|c|c|c|c|c|c|c|c|c|c|c|c|c|}
\hline \multirow{2}{*}{\multicolumn{3}{|c|}{ Genotypes }} & \multicolumn{2}{|c|}{$\begin{array}{l}\% \text { Fructose } \\
\text { in } D M\end{array}$} & \multicolumn{2}{|c|}{$\begin{array}{l}\% \text { Glucose } \\
\text { in DM }\end{array}$} & \multicolumn{2}{|c|}{$\begin{array}{l}\% \text { Sucrose } \\
\text { in } D M\end{array}$} & \multicolumn{2}{|c|}{$\begin{array}{l}\% \text { Dry } \\
\text { matter }\end{array}$} & \multirow{2}{*}{$\begin{array}{c}\text { Vol nectar } \\
\text { / floret } \\
\quad(\mu l)\end{array}$} & \multirow{2}{*}{$\begin{array}{c}\text { Energy val } \\
\text { / floret } \\
\text { (J) }\end{array}$} & \multirow[t]{2}{*}{$\begin{array}{r}\% \text { Oil } \\
\text { content }\end{array}$} \\
\hline & & & C & $E$ & $\mathrm{C}$ & $E$ & $c$ & $E$ & $c$ & $E$ & & & \\
\hline $\begin{array}{l}\text { B11A3 } \\
\text { GH } \\
\text { RHA266 } \\
\text { HA61 } \\
\text { V135 } \\
\text { B11A3 } \\
\text { GH } \\
\text { B11A3 } \\
\text { GH } \\
\text { F10 } \\
\text { B11A3 } \\
\text { GH } \\
\text { F10 }\end{array}$ & $\begin{array}{l}x \\
x \\
x \\
x \\
x \\
x \\
x \\
x\end{array}$ & $\begin{array}{l}\text { RHA266 } \\
\text { RHA266 } \\
\text { HA61 } \\
\text { HA61 } \\
\text { HA61 } \\
\text { V135 } \\
\text { V135 } \\
\text { V135 }\end{array}$ & $\begin{array}{l}51.5 \\
50.7 \\
50.9 \\
50.3 \\
50.7 \\
51.9 \\
54.0 \\
51.4 \\
50.8 \\
49.9 \\
52.5 \\
51.2 \\
51.3\end{array}$ & $\begin{array}{l}51.6 \\
48.2 \\
45.8 \\
51.5 \\
50.8 \\
53.3 \\
48.5 \\
50.8 \\
51.8 \\
51.0 \\
49.2 \\
50.3 \\
50.0\end{array}$ & $\begin{array}{l}48.5 \\
49.3 \\
47.3 \\
49.7 \\
49.3 \\
48.1 \\
46.0 \\
48.6 \\
49.2 \\
50.1 \\
47.5 \\
48.8 \\
48.7\end{array}$ & $\begin{array}{l}48.4 \\
46.4 \\
40.0 \\
47.1 \\
46.8 \\
41.6 \\
47.5 \\
43.1 \\
48.2 \\
48.4 \\
45.9 \\
44.5 \\
50.0\end{array}$ & 1.8 & $\begin{array}{r}5.4 \\
14.2 \\
1.4 \\
2.4 \\
5.1 \\
4.0 \\
6.1\end{array}$ & $\begin{array}{l}65.3 \\
32.3 \\
66.3 \\
73.3 \\
56.0 \\
50.0 \\
58.0 \\
68.0 \\
45.7 \\
63.7 \\
59.5 \\
53.0 \\
76.7\end{array}$ & $\begin{array}{l}74.0 \\
36.4 \\
60.8 \\
70.3 \\
69.0 \\
77.3 \\
59.6 \\
79.6 \\
60.2 \\
68.9 \\
73.7 \\
65.6 \\
81.5\end{array}$ & $\begin{array}{l}0.04 \\
0.26 \\
0.11 \\
0.08 \\
0.05 \\
0.09 \\
0.10 \\
0.04 \\
0.32 \\
0.09 \\
0.06 \\
0.29 \\
0.04\end{array}$ & $\begin{array}{l}0.44 \\
1.39 \\
1.17 \\
1.06 \\
0.50 \\
0.73 \\
0.95 \\
0.50 \\
2.73 \\
0.95 \\
0.67 \\
2.68 \\
0.50\end{array}$ & $\begin{array}{l}38.2 \\
46.7 \\
48.8 \\
43.4 \\
50.9 \\
40.5 \\
53.0 \\
42.9 \\
52.1 \\
44.2 \\
47.3 \\
49.9 \\
46.6\end{array}$ \\
\hline \multicolumn{3}{|c|}{$\begin{array}{c}\mathrm{F} \text { genotypes } \\
\text { Isd }\end{array}$} & \multicolumn{2}{|c|}{$0.70 \mathrm{~ns}$} & \multicolumn{2}{|c|}{$1.01 \mathrm{~ns}$} & & & \multicolumn{2}{|c|}{$\begin{array}{l}3.30^{\star \star} \\
19.23\end{array}$} & $\begin{array}{l}5.66^{\star \star} \\
0.12\end{array}$ & $\begin{array}{l}3.85^{\star \star} \\
1.14\end{array}$ & \\
\hline
\end{tabular}

F10 and from the hybrid F10 $\times$ RHA266 were not available. Correlations between the values obtained from both techniques were calculated for dry matter concentrations, and for the relative proportions of each constitutive sugar.

For dry matter concentration, calculations were made on data recorded from 3 samples per genotype and on the mean values of these 3 samples. The relative proportions of sugars were compared considering only the mean values. The correlation coefficients for the dry matter concentrations were significant both when considering the mean values $(r=0.78, n=13)$ and all samples $(r=0.36, n=39)$. However, the correlation coefficients calculated for fructose $((r=-0.17, n=13)$ and for glucose $(r=0.33$, $n=13$ ) were not significant, probably due to the high levels of sucrose detected by the enzyme electrode technique.

Since the enzyme electrode technology was not found very satisfactory and was carried out for one year only, further comparisons will only take into account data obtained from gas chromatography analysis.

\section{Composition}

This was the first factor studied in 1985 , since it was thought that qualitative differences could be more stable than quantitative observations. Table II gives the 1985 results of the $6 \times 6$ factorial. The 2 most important sugars are fructose and glucose. Sucrose is only found in small quantities (up to $4.2 \%$ of the dry matter) in 5 hybrids and 1 inbred, with no relation between them: the inbred was RHA 266, the hybrids had HA61 or PAC1 as male parent. The relative percentages of fructose and glucose appear quite standard (48-54\% and $46-52 \%$ respectively). Using the female parents as repetitions for the male parents, and reciprocally, no significant differences were shown. In table I, considering gas chromatography data, the overall 1986 results for the $3 \times 3$ factorial confirm that sucrose is present in traces only, the main sugars remaining fructose and glucose. Analysis of variance confirmed that there are no significant differences in the relative carbohydrate composition of the nectar produced by the genotypes studied. It may be considered as "sugar" as a whole. In contrast, significant variations in volume of nectar/floret, nectar dry matter content and energy value/floret appear. These quantitative characteristics were therefore studied in more detail.

\section{Quantitative characteristics}

\section{Volume of nectar per floret}

This character was studied in 1986 only (table I). Means for genotypes varied between 0.32 $\mu /$ floret for $\mathrm{GH} \times \mathrm{HA61}$ and $0.04 \mu \mathrm{l} / \mathrm{floret}$ for the inbred $\mathrm{B} 11 \mathrm{A3}$ and the hybrids F10 $\times$ V135 and 
Table II. Nectar production in 1985 and reaction to Sclerotinia by the inbred lines and hybrids of a $6 \times 6$ factorial cross.

\begin{tabular}{|c|c|c|c|c|c|c|}
\hline Genotype & $\begin{array}{l}\text { \% Fructose } \\
\text { in } D M\end{array}$ & $\begin{array}{c}\% \text { Glucose } \\
\text { in DM }\end{array}$ & $\begin{array}{c}\% \text { Sucrose } \\
\text { in DM }\end{array}$ & $\begin{array}{l}\% \text { Dry } \\
\text { Matter }\end{array}$ & $\underset{1}{\text { Sclerotinia }}$ & $\begin{array}{c}\text { Index } \\
2\end{array}$ \\
\hline
\end{tabular}

Inbred lines

B11A3
62
SD
GH
GU
F10
HA61
RHA274
RHA266
V135
PAC1
PRS5

Hybrids

B11A3 $\times$ HA61

$62 \times$ HA61

SD $\times$ HA61

$\mathrm{GH} \quad \times$ HA61

GU $\times$ HA61

F10 $\times$ HA61

B11A3 $x$ RHA274

$62 \times$ RHA274

SD $\times$ RHA274

GH $\times$ RHA274

GU $\times$ RHA274

F10 $\times$ RHA274

B11A3 $\times$ RHA266

$62 \times$ RHA266

SD $x$ RHA266

GH $\quad x$ RHA266

GU $x$ RHA266

F10 $x$ RHA266

$B 11 A 3 \times \frac{x}{}=135$

$62 \times$ V135

SD $\quad x \quad V 135$

$\mathrm{GH} \times \mathrm{V135}$

GU $x \quad V 135$

F10 $\times$ V135

B11A3 $x$ PAC1

$62 \times$ PAC1

SD $x$ PAC1

GH $\quad x \quad$ PAC1

GU $\quad x \quad$ PAC 1

F10 $x$ PAC1

B11A3 $x$ PRS5

$62 \times$ PRS5

SD $\times$ PRS5

GH $\times$ PRS5

GU $\times$ PRS5

F10 $\times$ PRS5

$\begin{array}{ll}52.13 & 47.87 \\ 50.39 & 49.61 \\ 52.17 & 47.83 \\ 49.74 & 50.26 \\ 50.79 & 49.21 \\ 48.61 & 51.39 \\ 49.90 & 51.10 \\ 48.04 & 51.96 \\ 48.95 & 50.74 \\ 50.28 & 49.72 \\ 51.53 & 48.47 \\ 50.04 & 49.96\end{array}$

50.06

48.21

49.75

51.04

52.28

51.76

51.99

50.32

50.90

49.91

50.53

49.53

51.77

50.73

50.90

53.15

52.62

50.14

52.91

49.03

54.37

49.05

50.17

52.14

51.58

49.50

51.18

51.86

50.01

52.11

51.32

53.84

53.16

52.92

50.83
47.87

47.83

50.26

51.39

51.10

50.74

48.47

49.96

48.50

47.57

49.64

48.65

47.72

48.24

48.01

49.68

49.10

50.09

49.47

50.47

48.23

49.27

49.10

46.85

47.38

49.86

47.09

50.97

45.63

50.95

49.83

47.86

48.42

50.25

48.82

48.14

49.99

47.89

48.68

46.16

46.84

47.08

49.17

$\begin{array}{rrr}47 & 143 & 89 \\ 27 & 157 & 79 \\ 57 & 161 & 127 \\ 40 & 360 & 83 \\ 57 & 219 & 78 \\ 41 & 379 & 61 \\ 68 & 122 & 108 \\ 53 & 196 & 103 \\ 50 & 182 & 101 \\ 53 & 146 & 81 \\ 44 & 69 & 94 \\ 46 & 123 & 93\end{array}$

1.44

4.22

0.61

0.31

(2)

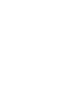

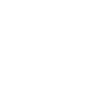

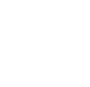

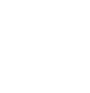

48

4

(2)

48

0.25

\begin{tabular}{|c|c|c|}
\hline 42 & 94 & 112 \\
\hline 62 & 88 & 99 \\
\hline 47 & 72 & 117 \\
\hline 31 & 132 & 116 \\
\hline 47 & 224 & 91 \\
\hline 62 & 133 & 97 \\
\hline 52 & 49 & 101 \\
\hline 70 & 105 & 97 \\
\hline 48 & 108 & 105 \\
\hline 35 & & 98 \\
\hline 39 & 246 & 83 \\
\hline 35 & 221 & 92 \\
\hline 47 & 254 & 92 \\
\hline 39 & 201 & 83 \\
\hline & 155 & 100 \\
\hline 48 & 233 & 83 \\
\hline 41 & 258 & 102 \\
\hline 68 & & \\
\hline 68 & & 80 \\
\hline 44 & 248 & 81 \\
\hline 42 & & 102 \\
\hline 67 & 581 & 84 \\
\hline 48 & 407 & 77 \\
\hline 26 & 270 & 73 \\
\hline 36 & 31 & 108 \\
\hline 40 & 145 & 85 \\
\hline 56 & 71 & 130 \\
\hline 50 & 152 & 93 \\
\hline 50 & 47 & 96 \\
\hline 39 & 35 & 86 \\
\hline 52 & 138 & 96 \\
\hline 47 & 82 & 83 \\
\hline 61 & 109 & 117 \\
\hline 58 & 363 & 83 \\
\hline 62 & 179 & 89 \\
\hline 57 & 158 & 88 \\
\hline
\end{tabular}

B11A3 $\times$ HA61. The 2 factorial analysis gave similar results (table III): there is no significant difference between male parents, whereas among the females, $\mathrm{GH}$ differs significantly from B11A3 and F10. Certain interactions are significant. Comparison between the inbreds and their hybrids shows only a very slight tendency to heterosis, the mean volume of nectar produced by the hybrids $(0.13 \mu \mathrm{l})$ being similar to that produced by the inbreds $(0.11 \mu \mathrm{l})$. The very large quantity of nectar produced by the inbred line $\mathrm{GH}$ appears heritable, for $\mathrm{GH} \times \mathrm{V} 135$ and GH $\times$ HA61 produce 2-3 times more nectar than the hybrids with B11A3 or F10 as female parent. However, the correlation between the 5 inbreds and the means of their hybrids, although quite 
Table III. Analysis of parental effects concerning the volume of nectar/floret $(\mu \mathrm{l})$.

Correlation inbred line - mean hybrid $r=0.70$ NS.

\begin{tabular}{lccc}
\hline Genotype & $\begin{array}{c}\text { Inbred } \\
\text { line }\end{array}$ & $\begin{array}{c}\text { Mean parental } \\
\text { Factorial } \\
2 F \times 3 M\end{array}$ & $\begin{array}{c}\text { efts in hybrids } \\
\text { Factorial } \\
3 F \times 2 M\end{array}$ \\
\hline B11A3 & 0.04 & 0.06 & 0.05 \\
GH & 0.26 & 0.22 & 0.31 \\
F10 & & & 0.06 \\
RHA266 & 0.11 & 0.10 & \\
HA61 & 0.08 & 0.18 & 0.15 \\
V135 & 0.05 & 0.17 & 0.13 \\
$F_{F}$ & & $21.13^{* *}$ & $19.01{ }^{\star *}$ \\
$F_{M}$ & & 2.08 NS & $0.38 \mathrm{NS}$ \\
$F_{\mathrm{r}}$ & & $4.64^{*}$ & $0.30 \mathrm{NS}$ \\
Isd $_{F}$ & & 0.07 & 0.08 \\
\hline
\end{tabular}

high $(r=0.71)$, is not significant, probably because 4 of the 5 lines are indistinguishable for this character.

\section{Dry matter concentration}

\section{Effect of year}

In order to determine whether the significant differences between genotypes observed in 1986 repeated 1985 results, an analysis of variance was made using the single 1985 value (table I) and the mean of the 1986 values (table II), for the 14 genotypes observed for both years. There was no significant year effect but no genotypic effects appeared either and the correlation between the 2 years was weak $(r=0.11 \mathrm{NS})$. However the 1986 results with 3 repetitions gave an Isd of 19.2 (table I), about $30 \%$ of the mean concentration, and these confidence limits cover a large part of the variation between 1985 and 1986. 1985 may be considered as simply showing the variability which occurs on 1 repetition.

\section{Heredity}

The factorial analysis were made using only 1986 results. In the absence of the inbred line $\mathrm{F} 10$ and the hybrid F10 $\times$ RHA266, 2 analysis were carried out (table IV) and they gave the same results. As in 1985, no significant parental effects or interactions may be demonstrated. The 3 male parents all give hybrids with $50-60 \%$ dry matter and this is true also of B11A3 and F10. Only the hybrids with $\mathrm{GH}$ as female parent show a slightly lower dry matter concentration. When the values for inbreds and their hybrids are compared (table IV), no heterosis appears, concentrations are sometimes slightly lower in hybrids. There is no significant correlation between inbreds and the means of their hybrids but GH has the lowest concentration of dry matter both as an inbred line and in its hybrids.

\section{Energy value}

This value was calculated by multiplying the weight of sugar/floret by the energetic yield provided by $1 \mathrm{mg}$ of sugar (16.725 J) (Bolten et al, 1979). The results (table $V$ ) resemble those for nectar volume/floret with $\mathrm{GH}$ differing from the other genotypes, both as an inbred line and in its hybrids.

Table IV. Analysis of parental effects concerning the percentage dry matter content in nectar.

Correlation inbred line - mean hybrid $r=0.02$ NS.

\begin{tabular}{lccc}
\hline Genotype & $\begin{array}{c}\text { Inbred } \\
\text { line }\end{array}$ & $\begin{array}{c}\text { Mean parental effects in hybrids } \\
\text { Factorial } \\
2 F \times 3 M\end{array}$ & $\begin{array}{c}\text { Factorial } \\
3 F \times 2 M\end{array}$ \\
\hline B11A3 & 65.3 & 59.2 & 64.3 \\
GH & 32.3 & 51.6 & 49.3 \\
F10 & & & 68.5 \\
RHA266 & 66.3 & 54.0 & \\
HA61 & 73.3 & 55.8 & 59.5 \\
V135 & 56.0 & 56.3 & 61.9 \\
$F_{F}$ & & $1.05 \mathrm{NS}$ & $3.19 \mathrm{NS}$ \\
$\mathrm{F}_{\mathrm{M}}$ & & $0.06 \mathrm{NS}$ & $0.14 \mathrm{NS}$ \\
$\mathrm{F}_{\mathrm{r}}$ & & $1.67 \mathrm{NS}$ & $0.86 \mathrm{NS}$ \\
\hline
\end{tabular}

Table V. Analysis of parental effects concerning the energy value per floret $(\mathrm{J})$.

Correlation inbred line - mean hybrid $r=0.33$ NS.

\begin{tabular}{lccc} 
Genotype & $\begin{array}{c}\text { Inbred } \\
\text { line }\end{array}$ & $\begin{array}{c}\text { Mean parental effects in hybrids } \\
\text { Factorial } \\
2 F \times 3 M\end{array}$ & $\begin{array}{c}\text { Factorial } \\
3 F \times 2 M\end{array}$ \\
\hline B11A3 & 0.44 & 1.04 & 0.59 \\
GH & 1.39 & 2.11 & 2.70 \\
F10 & & & 0.72 \\
RHA266 & 1.17 & 0.84 & \\
HA61 & 1.06 & 1.61 & 1.39 \\
V135 & 0.50 & 1.67 & 1.28 \\
$F_{F}$ & & $12.37^{* *}$ & $10.09 * *$ \\
$F_{M}$ & & $1.63 \mathrm{NS}$ & $0.06 \mathrm{NS}$ \\
$\mathrm{F}_{r}$ & & $2.26^{*}$ & $0.17 \mathrm{NS}$ \\
Isd $_{F}$ & & 0.11 & 1.06 \\
\hline
\end{tabular}




\section{Pollen}

\section{Differences between plants}

In all cases, for inbreds or hybrids, the differences between plants were highly significant (with $F$ values of $15.2-40.7$ for the inbreds and 12.4-1 268.7 for the hybrids with $4 / 12 \mathrm{df}$ ). In hybrids, for a general mean of 34268 pollen grains/floret, the Isd varies from 5001000 . Thus, the 4 counts on each plant show good repeatability, but non genetic factors cause variation between plants.

\section{Differences between genotypes}

Analysis of variance between genotypes, using the plant means, showed significant differences both between inbreds and between hybrids (table
$\mathrm{VI})$ although with lower $\mathrm{F}$ values and higher Isd than between plants. Pollen grain number per floret varies from 25218 (F10) to 42087 (B11A3 $\times$ RHA274) with a mean of 35570 grains/floret for hybrids and 32843 grains/floret for inbred lines. Of the 17 hybrids for which comparison with the 2 parents is possible, 10 show heterosis.

As results were available for only 25 hybrids of the possible 36, 3 factorial analysis were carried out using different combinations to determine parental effects (table VII). In all cases, female, male and interaction effects were significant. Of the female parents, $\mathrm{B} 11 \mathrm{~A} 3$ always gave hybrids which produced a lot of pollen, F10 gave hybrids with significantly less. SD and 62 (table VI) were not significantly different. Considering the male parents, HA61 and PRS5 gave hybrids with a lot of pollen, PAC1 and RHA266 were intermediate

Table VI. Numbers of pollen grains per floret and oil contents of inbred lines and hybrids.

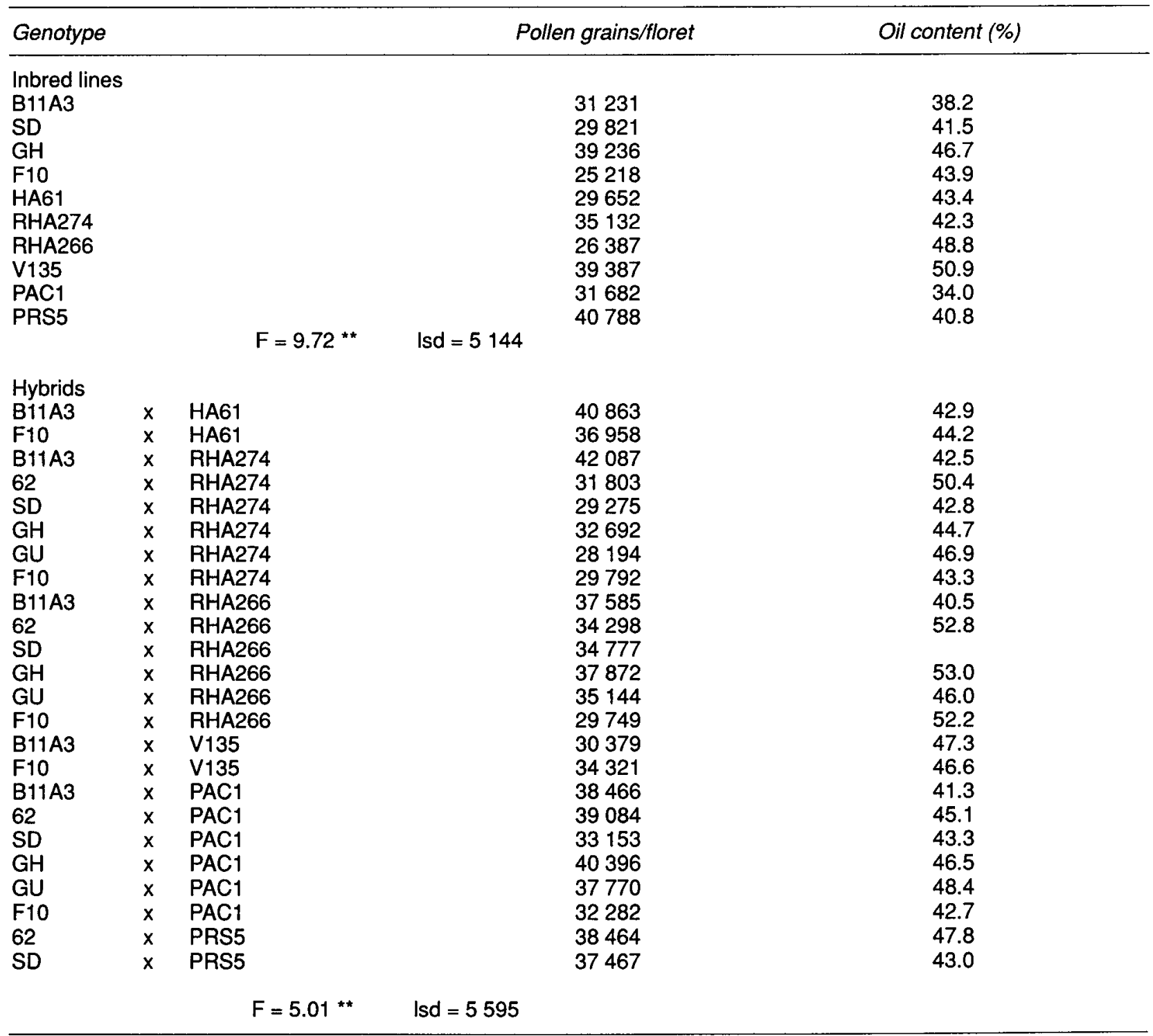


Table VII. Analysis of parental effects concerning the number of pollen grains per floret.

\begin{tabular}{|c|c|c|c|c|}
\hline \multirow[t]{2}{*}{ Genotype } & \multirow[t]{2}{*}{ Inbred line } & \multicolumn{3}{|c|}{ Mean parental effects in hybrids } \\
\hline & & $\begin{array}{c}\text { Factorial } \\
A\end{array}$ & $\begin{array}{c}\text { Factorial } \\
B\end{array}$ & $\begin{array}{c}\text { Factorial } \\
C\end{array}$ \\
\hline B11A3 & 31231 & 39379 & 37876 & 39632 \\
\hline SD & 29822 & 32401 & & 33668 \\
\hline F10 & 25218 & 30607 & 32620 & \\
\hline HA61 & 29652 & & 40260 & \\
\hline RHA274 & 35132 & 32307 & 35940 & 34388 \\
\hline RHA266 & 26397 & 34904 & 33667 & 35553 \\
\hline V135 & 39277 & & 32350 & \\
\hline PAC1 & 31682 & 36859 & 35374 & 36901 \\
\hline PRS5 & 40788 & & & 38774 \\
\hline $\begin{array}{l}F_{F} \\
F_{M} \\
F_{r} \\
I_{s d_{F}} \\
l_{s d_{M}}\end{array}$ & & $\begin{array}{c}11.84 \text { ** } \\
12.28 \text { ** } \\
2.99 \text { ** } \\
1852 \\
2619\end{array}$ & $\begin{array}{c}23.00^{\star \star} \\
4.13^{\star \star} \\
5.97^{\star \star} \\
2203 \\
3483\end{array}$ & $\begin{array}{c}14.32^{\star \star} \\
4.20^{\star \star} \\
3.38^{\star \star} \\
2263 \\
2613\end{array}$ \\
\hline \multicolumn{5}{|c|}{ Correlation inbred line - mean hybrid } \\
\hline & $r$ & $0.40 \mathrm{NS}$ & 0.06 NS & $0.38 \mathrm{NS}$ \\
\hline
\end{tabular}

and not significantly different, hybrids with V135 had the least pollen, those with RHA274 varied according to the female parent.

As might be expected with significant interactions between parents, the phenotypic correlation between inbreds and the means of their hybrids was not significant (according to combination, $r$ varied between 0.06 and 0.40 $N=7, N S)$. Nevertheless, it may be noted that F10 and $S D$ always give relatively little pollen, B11A3 and PRS5 greater quantities.

\section{Relations with nectar production}

Nectar dry matter production did not appear significantly correlated with pollen production in $1985(r=0.08, N=33)$ or in $1986(r=0.42$, $N=10)$.

\section{Relation of nectar and pollen with Sclerotinia reaction and oil content}

\section{Sclerotinia reaction}

The results of Sclerotinia observations are given in table II. Table VIII gives the series of correlations established with 1985 and 1986 results for nectar and 1985 results for pollen. For nectar, when a wide range of genotypes was studied, no correlation appeared. However, correlations between reaction of different genotypes to natural attack and their volume of nectar/floret and energy value are significant. This could be a biological relation but the significantly different nectar production by $\mathrm{GH}$, a line very susceptible to Sclerotinia, may be the reason for these correlations. It would be necessary to study a wider range of genotypes to determine the true relation. In the case of pollen, no significant correlations with Sclerotinia reaction were shown, but the hybrids show a slight tendency to greater susceptibility when less pollen is produced.

\section{Oil content}

The oil contents of the inbred lines and hybrids studied for their pollen production are given in table VI. The correlation coefficients: pollen number - oil content, $r=0.13, N=11$ (inbreds) and $r=-0.23, N=24$ (hybrids) are not significant, although they show a slight tendency for genotypes producing less pollen to have higher oil contents.

The oil contents of the genotypes on which nectar production was studied are given in table I. The correlations with energy value/floret were $r=0.51(N=13$, all material) and $r=0.60$ ( $N=8$, hybrids only). Both results are just below the significance level, but again $\mathrm{GH}$ may be the preponderant cause. It may be noted that $\mathrm{GH}$ 
Table VIII. Correlations between nectar or pollen production and Sclerotinia reaction.

\begin{tabular}{|c|c|c|c|c|c|c|c|}
\hline & & \multicolumn{2}{|c|}{ Nectar } & \multirow[b]{2}{*}{$\begin{array}{c}\text { Vol/ } \\
\text { floret }\end{array}$} & \multirow[b]{2}{*}{$\begin{array}{c}\text { Energy } \\
\text { val }\end{array}$} & \multicolumn{2}{|c|}{ Pollen } \\
\hline & & $\begin{array}{c}\% D M \\
1985\end{array}$ & $\begin{array}{c}\% D M \\
1986\end{array}$ & & & $\begin{array}{c}\text { Inbreds } \\
1985\end{array}$ & $\begin{array}{c}\text { Hybrids } \\
1986\end{array}$ \\
\hline $\begin{array}{l}\text { Sclerotinia } \\
\text { natural } \\
\text { attack }\end{array}$ & $\stackrel{r}{N}$ & $\begin{array}{c}0.14 \\
31\end{array}$ & $\begin{array}{c}-0.40 \\
13\end{array}$ & $\begin{array}{c}0.55^{*} \\
13\end{array}$ & $\begin{array}{c}0.51^{\star} \\
13\end{array}$ & $\begin{array}{c}0.03 \\
10\end{array}$ & $\begin{array}{c}-0.27 \\
25\end{array}$ \\
\hline $\begin{array}{l}\text { Sclerotinia } \\
\text { ascospore } \\
\text { test }\end{array}$ & $\stackrel{r}{N}$ & $\begin{array}{c}0.04 \\
35\end{array}$ & $\begin{array}{c}0.08 \\
13\end{array}$ & $\begin{array}{c}0.19 \\
13\end{array}$ & $\begin{array}{c}0.30 \\
13\end{array}$ & $\begin{array}{c}0.08 \\
10\end{array}$ & $\begin{array}{c}0.19 \\
25\end{array}$ \\
\hline
\end{tabular}

and, to a less extent RHA266, have high nectar and oil contents, whereas B11A3 has a low nectar and oil content.

\section{DISCUSSION}

\section{Nectar production}

\section{Methodology}

Various methods of nectar analysis are available.

* The volume of nectar per floret may be determined from different collection methods. As an effect of collection method on estimation of nectar production was noted by Girnik (1976), who preferred micropipette collection to both centrifugation and washing, pipette collection was used in our work.

* The concentration of total sugars in samples of several $\mu$ l of nectar can be measured with a refractometer (Heinrich and Raven, 1972), or by summing the constitutive sugars as in our work.

* The carbohydrate composition of nectar may be identified using paper (Scogin, 1979), thinlayer (Brewer et al, 1974) and gas-liquid (Bieleski and Redgwell, 1980) chromatographic techniques. In the present work, analysis were conducted firstly using gas chromatography described by Bosi (1973), adapted following Black and Bagley (1978). This method allowed a reliable determination of nectar sugars from small nectar samples but needed a complete derivatisation of the mono- and bi- saccharides before gas chromatography analysis, which involved a rather time-consuming procedure. In order to test another possibly more rapid method, the same nectar samples were analysed with enzyme electrode technology, usually applied for sugar analysis in foodstuffs.

The 2 methods gave equivalent results for dry matter but differed particularly in the determination of the presence/absence of sucrose and the concentrations of this compound. Higher amounts of sucrose found from the enzyme electrode method appear to be related to the estimation procedure in which the quantity of sucrose is deducted from a double reading of glucose before and after inversion. In addition, it should be noted that galactase oxidase is a relatively non specific enzyme, and there may be substrates present in nectar samples which could interfere. Gas chromatographic analysis thus appear preferable for further analysis. The use of high-performance liquid chromatography may be suggested, since the development of this technique has allowed several authors to conduct rapid and reproductible determinations of nectar carbohydrate composition (Erickson et al, 1979; Freeman et al, 1983).

\section{Genetic variability}

\section{Qualitative characteristics}

Analysis in 1985 and 1986 confirm that the 3 sugars that may be present in nectar are glucose, fructose and sucrose, as previously shown in sunflower, using the same technique (Bosi, 1973; Fonta et al, 1985) and using paper chromatography (Wykes, 1952). Bosi detected another sugar, raffinose, which may depend on the genotypes considered. However, although chosen for their genetic diversity, neither the group of 36 hybrids, nor the group of 9 hybrids showed any significant variation, with only trace quantities of sucrose in a few lines, and stable proportions of about $52 \%$ fructose and $48 \%$ glucose. Inbred lines comparable with the female parent of the hybrid Mariane, whose nectar contains up to $50 \%$ sucrose, reported by Fonta et al (1985), do not appear common. These authors suggested that it might be possible to characterise sunflower lines according to the 
quality of their nectar. The present results suggest that by carbohydrate composition it would rarely be possible to do this. However, it must be kept in mind that many other nectar constituents may characterise sunflower genotypes. More particularly, the occurrence of amino acids, although the amounts are small in comparison with the sugars, may be significant nutritionally for bees.

\section{Quantitative characteristics}

The 1986 results indicate that some repeatable quantitative differences occur.

Sunflower nectar secretions are reported to vary from 0.02 to $0.16 \mu \mathrm{l}$ per floret (Tepedino and Parker, 1982). Some of the measurements reported here are higher than these values, perhaps due to the genotypes considered. There were significant differences between genotypes, and 1 inbred line, $\mathrm{GH}$, had significantly more nectar than any of the others, both for per se values $(0.26 \mu \mathrm{l} /$ /loret) and for 2 of its 3 hybrids. Increased nectar production appears dominant in the case of $\mathrm{GH} \times \mathrm{HA61}(0.32 \mu \mathrm{l} / \mathrm{floret})$ and GH $\times$ V135 $(0.29 \mu l)$ but for GH $\times$ RHA266 $(0.10 \mu l)$ the nectar level is close to that of the male parent RHA266 $(0.11 \mu l)$ which with a moderate quantity of nectar both in the inbred line and in its hybrids $(0.09$ to $0.11 \mu l)$ also appears to contain some dominant genes.

It is difficult to advance further in the study of heredity for, with the exception of $\mathrm{GH}$, the 5 other inbred lines are not significantly different. It would appear that genotypes producing a very large quantity of nectar are quite rare.

Total sugar concentration (dry matter) values from $30-50 \%$ are usually reported in sunflower (Burmistrov, 1965; Parker, 1981b). Although covering this range, in both 1985 and 1986, genotypes such as $\mathrm{HA61}$ and $\mathrm{F} 10 \times \mathrm{V} 135$ contained $70 \%$ or more. The results obtained in 1986 showed significant differences between genotypes but no significant parental effects. This confirmed the 1985 results where there were no parental effects either. However, taking the genotypes studied over the 2 years, the correlation was not significant. This provides an indication of the variability which may occur in quantitative measurements of nectar, if samples are not taken from plants under the same conditions.

Sunflowers thus appear to produce nectar in which a quite constant series of sugars are produced and in which the dry matter concentration does not vary considerably. Genotypes appear to differ most for the activity of their nectar secretion.

\section{Relations with agronomic characters}

There were no significant correlations between Sclerotinia resistance and nectar production in 1985. With the $3 \times 3$ factorial, correlations appear between Sclerotinia resistance and volume of nectar and energy value per floret and almost at a significant level between oil content and energy value per floret. However, it must be noted that these results depend largely on the inbred $\mathrm{GH}$ and its hybrids, which have large quantities of nectar, high oil contents and are susceptible to Sclerotinia. For all the other genotypes there does not appear to be any direct relation between nectar production and oil content or disease resistance. Nectar production does not appear to be a useful marker character for Sclerotinia resistance.

\section{Pollen production}

The 4 counts of pollen grain numbers per floret on any 1 plant showed that the method has good repeatability, as already reported by Loublier et al (1986). However, all the measurements on different plants and on different genotypes showed considerable variability. Hereditary effects can be distinguished (significant $F$ genotype, $F$ parental effects) but there are considerable interactions between parents of hybrids and environmental sources of variation (differences between plants of 1 genotype). It is difficult to explain these last variations, for differences in vigour between plants of 1 genotype do not appear to be involved, since the more vigorous hybrids frequently do not have more pollen than the inbred lines.

Between hybrid genotypes the number of grains varies from 28 to 40 thousand per floret. Significant differences mean that it would be possible to select genotypes with increased or decreased pollen production. However, although good pollen production is necessary in male parents and increased numbers of pollen grains appear to be slightly related to decreased Sclerotinia susceptibility (perhaps because they give more rapid fertilisation and so a reduced period of Sclerotinia susceptibility), the relation with oil is the reverse. A saving in energy use for pollen production could permit increased oil production. Vear and Tourvieille de Labrouhe (1988) report a significant negative correlation between Sclerotinia resistance and oil content in the material studied and variation in pollen number may be linked with this relation.

In conclusion, satisfactory methods have been developed for measuring nectar and pollen 
production in sunflowers but the results of genetical studies are rather negative since there appears to be little variation in nectar production and, on the contrary, almost excessive variation in pollen production. There do appear to be some relations with agronomic characters, but these need further and wider studies and, in addition, may be favorable or unfavorable. No direct breeding programme concerning nectar or pollen production can be proposed until a further understanding of their physiology and roles in sunflower development, and possible interactions with environmental conditions, has been obtained.

\section{ACKNOWLEDGMENTS}

The authors wish to thank $\mathrm{Dr} C$ Masson for helpful comments and criticisms.

\section{REFERENCES}

Baker I, Baker H (1976) Analyses of amino-acids in flower nectar of hybrids and their parents, with phylogenetic implications. New Phytol 76, 87-98

Bieleski RL, Redgwell RJ (1980) Sorbitol metabolism in nectaries from flowers of Rosaceae. Aust J Plant Physiol 7, 15-25

Black LT, Bagley EB (1978) Determination of oligo saccharides in soybeans by high pressure liquid chromatography using an internal standard. $J$ Ann Oil Chemist Soc 55, 228-232

Brewer JW, Collyard KJ, Lott CE (1974) Analysis of sugars in dwarf mistletoe nectar. Can $J$ Bot 52, $2533-2538$

Bolten AB, Feinsinger P, Baker HG, Baker I (1979) On the calculation of sugar concentration in flower nectar. Oecologia 41, 301-304

Bosi G (1973) Méthode rapide pour la détermination par chromatographie en phase gazeuse des glucides du nectar: technique de prélèvement du nectar et de préparation des éthers triméthylsilylis en présence d'eau. Apidologie 4, 57-64

Brohst KM, Lott CE (1966) Determination of some components in corn syrup by gas-liquid chromatography of the trimethyisilyl derivatives. Cereal Chem 43, 35-43

Burmistrov AN (1965) The melliferous value of some sunflower varieties. 20th Int Apic Congr Bucharest, 320-323

Buzon J, Guichard N, Lebee J, Provot A, Serpinet J, Tranchant J (1968) Manuel pratique de la chromatographie en phase gazeuse. Masson, Paris, $357 \mathrm{p}$

Erdtman G (1960) The acetolysis method: A revised description. Sven Bot Tidskr 54, 561-564

Erickson EH, Thorp RW, Briggs DL, Estes JR, Daun RJ, Marks M, Schroeder CH (1979) Characterisation of floral nectars by highperformance liquid chromatography. J Apic Res 18, 148-152
Etievant PX, Azar M, Pham-Delegue MH, Masson CJ (1984) Isolation and identification of volatile constituents of sunflower (Helianthus annuus L). J Agric Food Chem 32, 503-509

Fonta C, Pham-Delegue MH, Marilleau R, Masson C (1985) Rôle des nectars de tournesol dans le comportement des insectes pollinisateurs et analyse qualitative et quantitative des éléments glucidiques de ces sécrétions. Acta Oecol Oecol App/ 6, 175-186

Freeman CE, Reid WH, Becvar JE (1983) Nectarsugar composition in some species of agave (Agavaceae). Madrono 30, 153-158

Freund DE, Furgala B (1982) Effect of pollination by insects and the seed set and yield of ten oilseed sunflower cultivars. Am Bee J 122, 648-652

Furgala B, Noetzel DM, Robinson RG (1979) Observations on the pollination of hybrid sunflowers. Proc IV Int Symp Pollination, College Park 1978, 45-48

Girnik D (1976) Productivité en nectar du tournesol. Pchelovodstvo 8, 10-11

Harbourne JB, Smith DM (1978) Anthochlors and other flavonoids as honey guides in the Compositae. Biochem System Ecol 6, 287-291

Heinrich B, Raven PH (1972) Energetics and pollination. Science 176, 597-602

Loublier Y, Douault P, Pham-Delegue MH (1986) Méthode de comptage automatique des grains de pollen: étude de la production pollinique chez le tournesol (Helianthus annuus L), Compositae. Apidologie 17, 245-256

MacGregor SE (1976) Insect pollination of cultivated crop plants. Agric Handbook US Dep Agric n ${ }^{\circ} 496$, Washington DC, 411

Parker FD (1981a) Sunflower: abundance, diversity and seasonality of bees on male-sterile and malefertile cultivars. Environ Entomol 10, $1012-1017$

Parker FD (1981b) Sunflower pollination: abundance, diversity and seasonality of bees and their effects on seed yields. J Apic Res 20, 49-61

Pham-Deleque MH, Fonta C, Masson C, Douault $P$ (1985) Etude comparée du comportement de butinage d'insectes pollinisateurs (abeilles domestiques (Apis mellifera $\mathrm{L}$ ) et bourdons (Bombus terrestris L)) sur les lignées parentales d'hybrides de tournesol (Helianthus annuus L). Acta Oecol, Oecol Appl 6, 47-67

Radford BJ, Rhodes JW, Nielson RGH (1979) Seed set in sunflower crops in the Central Darling Downs, Queensland. J Anim Sci 36, 133-139

Renard M, Mesquida J, Pellan-Delorme R, Pelletier G, Morice J (1987) Pollinisation des hybrides mâlesstériles dans un système de culture mixte de colza. In: Variabilité génétique cytoplasmique et stérilité mâle cytoplasmique. (Bervillé A, ed). Les colloques de l'INRA 45, 281-292

Says-Lesage V, Tourvieille de Labrouhe D (1988) Recherche des sites de pollution et d'infection de fleurons de tournesol, in situ par les spores de Sclerotinia sclerotiorum. Inf Tech CETIOM 102, 3-13

Scogin R (1979) Nectar constituents in the genus Fremontia (Stericulaceae) : sugars, flavonoids and proteins. Bot Gaz 140, 29-31 
Stanley RG, Linskens HF (1974) Pollen: Biology, biochemistry, management. Berlin, Springer-Verlag, $307 p$

Stanton ML, Preston RE (1988) A quantitative model for evaluating the effects of flower attractiveness on male and female fitness in plants. Am $J$ Bot 75, 157-159

Tepedino VJ, Parker FD (1982) Interspecific differences in the relative importance of pollen and nectar to bee species foraging on sunflowers. Environ Entomol 11, 246-250

Tourvieille de Labrouhe D, Vear F (1984) Comparaison de méthodes d'estimation de la résistance du tournesol à Sclerotinia sclerotiorum (Lib) de Bary. Agronomie 4, 517-525
Vear $F$ (1984) The effect of male sterility on oil content and seed yield in sunflower. Agronomie 4, 901-904

Vear F, Tourvieille de Labrouhe D (1987) Le jugement des hybrides de tournesol vis-à-vis de l'infection naturelle des capitules par Sclerotinia sclerotiorum. Inf Tech CETIOM 99, 9-14

Vear F, Tourvieille de Labrouhe D (1988) Relations between oil content and resistance to Sclerotinia sclerotiorum in sunflowers. Proc XIlth Int Sunflower Conf Novi-Sad, Yugoslavia, 110-114

Weast RC (1988) Handbook of Physics and Chemistry. 68th ed (West RC ed) CRC Press Inc, Boca Roton, Florida, USA, $241 \mathrm{p}$

Wykes GR (1952) An investigation of the sugars present in the nectar of flowers of various species. New Phyto/ 51, 210-215 